\title{
SIGNIFICANCE OF THE "POLLUTANT PAYS" PRINCIPLE AND THE ANALYSIS OF THE EUROPEAN FRAMEWORK FOR A CIVIL LIABILITY FOR DAMAGES CAUSED BY ACTIVITIES DANGEROUS TO THE ENVIRONMENT
}

\begin{abstract}
The right to a healthy environment is an absolute priority of the modern society. A specific economic instrument aimed at protecting the environment at a global level is the compensation for environmental pollution, based on a principle of environmental protection called "pollutant pays". The essence of a civil liability for environmental damage is that potential pollutants should adjust their activities to the requirement of causing minimal changes in the environment and reducing the risk of damage to a minimum. In addition to the significance and characteristics of the "pollutant pays" principle, the paper presents the provisions of the Act on Environmental Protection. There is also included an analysis of the provisions of the Convention on civil liability for damage caused by environmental hazards, and the provisions of the Environmental Liability Directive related to the protection and elimination of environmental damage.
\end{abstract}

* LLD, Associate Professor, The Faculty for construction menagement, The "Union - Nikola Tesla" University, Serbia, e-mail: bodraskovic@gmail.com

** LLM, PhD candidate at the Faculty of Law for Commerce and Judiciary, The University of Business Academy in Novi Sad, Serbia, e-mail: odvjetnik.olga.perovic@gmail.com

(c) () (C) 2021 by the authors. This article is an open access article distributed under the terms and conditions of the Creative Commons Attribution (CC BY) license (https://creativecommons. org/licenses/by/4.0/). 
Keywords: Pollutant pays, environment, civil liability, The Act on Environmental Protection, the EU regulations

\section{Introduction}

The concept of environmental sustainability is one of the primary principles based on the human right to a healthy environment. It is woven into regulations of a national character (Constitution, laws, and strategies), as well as into the most important European and global policies and principles.

The environment "represents everything that surrounds us, that is, everything with which human life and production activity is directly or indirectly connected" (Hamidović, 2012, p. 235). Therefore, the human right to a healthy environment is one of the basic human rights. According to Article 74 of the Constitution of the Republic of Serbia (2006), "everyone has the right to a healthy environment and to timely and complete information on its condition." However, during his activities, man changes the natural environment, often by disturbing the natural environment.

Preservation and protection of the environment is an imperative in modern society. The environment is basically one of the pillars of sustainable development. In this context, "environmental principles belong to the group of basic principles on which sustainable development, in general, is based, especially sustainable development of rural parts of a certain territory, and imply primary respect for the natural diversity of the destination" (Cvijanović et al., 2017, p. 871), and it can be emphasized that "sustainable development basically means finding a balance between social development, economic progress, and environmental protection” (Matijašević Obradović, 2017, p. 22). According to Jovašević (2009), "finding the optimal relationship between unhindered economic growth and development and the preservation and protection of the environment is not an easy task" (p. 26).

Preservation of the environment is also an unavoidable factor in the internal stability and security of a country. However, the problem of endangering the environment has long been not just a problem of internal security. According to Labudović Stanković (2012), “constant environmental pollution is a constant companion of modern economic development" (p. 1262).

Sources of environmental pollution and its elements, according to some views, in theory, can be natural and artificial (anthropogenic). Natural sources are "all processes that take place in the biosphere against the will of man (volcanoes, earthquakes, cosmic dust). Artificial (anthropogenic) are the products of all human activities (extraction and processing of mineral raw materials, thermal and 
nuclear power plants, agriculture, industry, transport, tourism and other activities such as sports, recreation, and household pollutants)" (Đorđević, 2018, p. 466). Indicators of endangering the environment "give us the right to determine that the social causes of endangerment are more prevalent than natural ones and that the organization of the system of its protection and improvement depends on understanding the causes of endangerment" (Keković \& Todorović, 2008, p. 24).

A specific economic instrument provided by the Law on Environmental Protection (2004) aimed at environmental protection is the compensation for environmental pollution, based on a specific principle of environmental protection called "polluter pays". According to Article 9 item 6 of the Law on Environmental Protection (2004) "a polluter pays a fee for environmental pollution when his activities cause or may cause a burden on the environment, ie if he produces, uses, or places on the market raw materials, semi-finished products or products containing harmful substances for the environment." The same point also stipulates that "the polluter bears the total costs of measures to prevent and reduce pollution, which include the costs of environmental risks and the costs of eliminating the damage caused to the environment." The Law on Integrated Prevention and Control of Environmental Pollution (2004) has a similar wording where Article 3 item 5 states that "the polluter must bear the full costs of the consequences of self activities, the costs incurred by endangering the environment which includes the costs of endangering and the risk to the environment, and the costs of removing the damage caused to the environment that is returning the site to a satisfactory state of the environment after the closure of the plant or the cessation of activities." The polluter, therefore, by the regulations, bears the total costs of measures to prevent and reduce pollution, which include the costs of environmental risks and the costs of eliminating the damage caused to the environment.

The following subtitle discusses the question of responsibility and the significance of the "polluter pays" principle. Then, the paper will deal with the issue of how the European framework of civil liability for damages caused by activities dangerous to the environment is regulated because the regulations of the European Union are an important foundation for national legislation.

\section{Significance and characteristics of the "polluter pays" principle}

Liability, according to the "polluter pays" principle is a special type of polluter liability, based on objective responsibility for the pollution of the environment. The introduction of this principle into our legislation, legally 
based on international regulations, is primarily on the founding acts of the European Union, and then the conventions and directives of the European Union.

The legal principle "polluter pays" starts from the "principle of fairness, the reasonable assumption that the person who caused the risks to the environment should bear both the costs of precautionary measures and the costs arising from prevention, as well as eliminating the consequences of damage caused by pollutants" (Pajtić, 2015, p. 1672).

What makes this principal characteristic is that it is about future damage that occurs or may occur due to the undertaking of activities by polluters. Article 3, item 14 of the Law on Environmental Protection (2004) stipulates that "polluter" means "a legal or natural person who, by his activity or inactivity, pollutes the environment." Therefore, the formulation of the specific responsibility of polluters is for preventive action, for prevention of excessive environmental pollution.

According to Pajtić (2011a), "civil liability exists if the damage to protected goods is measurable and if the consequence consists in endangering or injuring the personal property or non-property assets of a natural or legal person. These damages are eliminated utilizing the classic right of compensation. In our legislation, the prevention of damage to protected goods is one of the basic goals of the legal policy of environmental protection" (p. 518).

The principle of "polluter pays" according to Zindović (2012), "is founded through two attributes, namely: ratione personae, because it is known in advance who pays and ratione temporis, because payment refers only to future damage" (p. 277). Here, Počuča and Milić (2018) define the essence of this principle in the sense that "instead of the costs of its repair being charged from the one who caused the damage and caused by the perpetrator, according to this principle, the operator's payment refers to future damage" ( p. 236). It is, however, an "instrument of tax policy that directs the behavior of polluters towards the adoption of better options and practices from the point of view of environmental protection goals" (Pajtić, 2015, p. 1672). And precisely in the context of preventive activities in the field of environmental protection, Cvetić (2013) states that "the essence of the principle of prevention and precaution is that every person, all his associations and society as a whole, adjust their activities to the requirement to cause minimal changes in the environment. the risk of damage is reduced to a minimum" (p. 124).

The principle of "polluter pays", as Popov (2013) points out, "belongs to the group of fundamental principles on which European environmental policy is based, and given that the polluter is responsible for eliminating the 
environmental damage, this is a reactive principle of prescribing costs for remediation of environmental damage" (p. 137).

Compensation for future damage according to the "polluter pays" principle in concreto must be proportionate to the risk and effects of the activities undertaken by the polluter, which could potentially cause harmful consequences for the environment.

In this section, Salma (2009) states that "in some countries, such as Austria and Germany, absolute liability has been introduced under special legislation for the environmental consequences of nuclear power plant accidents, especially for consequences in terms of damage to public health or death, whereby the law provided for a fixed compensation for each of these damages for each injured party. Absolute responsibility is responsibility in which even force majeure is not a reason to exclude responsibility" (p. 35). It is known, however, that "in the case of ,ordinary" objective liability, liability regardless of guilt, if the damage was caused by force majeure, there is no liability of the holder of the dangerous item or the holder of the dangerous activity" (Salma, 2009, p. 35).

The principle of prevention in dealing with potentially dangerous activities of pollutants is also specified in the provisions of Article 156 of the Law on Obligations (1978), which stipulates that "one may require from the other to remove the source of the danger from which significant damage is threatened to a person or an indefinite number of persons, as well as to refrain from the activity from which the harassment or danger of damage arises if the occurrence of harassment or damage cannot be prevented by appropriate measures."

Considering various aspects of the application of the "polluter pays" principle, it should be noted that "polluters should bear the costs of pollution control measures such as the formation and operation of installations that prevent the spread of pollution, investment inappropriate equipment and new processes that prevent pollution. to achieve the required quality of the environment" (Tubić, 2012, p. 504).

Bingulac and Milojević (2018) here justifiably ask the question of what position to take "when there are situations in which it is not possible to identify the polluter, so this can be extended to the aspect of whether responsibility will be distributed according to the principle of equality contributed to the pollution, or will the responsibility be on the one who caused the pollution first" (p. 202)? Consulting the provisions of the 1974 Recommendation of the Council of the European Community (Recommendation OECD / LEGAL/0132), Tubić (2012) states that "in such cases, the costs of pollution 
should be determined by legal or administrative means, which provide the best solution. In the case of a series of pollution, costs should be charged at a time when the number of economic factors is lower and control is easiest or at a time when it is possible to make the most effective contribution to improving the environment" (p. 503).

Given that national legislation is based on the legal framework of the European Union, in the context of the topic of the paper, it is important to present in more detail the provisions of the Law on Environmental Protection concerning the principle of "polluter pays", then the Council of Europe Convention on Civil Liability resulting from activities dangerous to the environment (1993), which is the basis of objective liability of polluters for damage that the polluter may cause during its activities, as well as the Directive of the European Parliament and the Council on liability for environmental damage 2004/35/CE.

\section{The "polluter pays" principle in the Law on Environmental Protection}

Article 103 of the Law on Environmental Protection (2004) stipulates that "the polluter who causes environmental pollution is liable for the damage caused according to the principle of strict liability. Also, the legal and physical person who enabled or allowed the pollution of the environment by illegal or incorrect actions is responsible for the environmental pollution."

The legislator regulates liability for damage in Article 105 of the same Law, wherein paragraph 1 stipulates that the polluter is responsible for the damage caused to the environment and space and bears the costs of damage assessment and its removal, and in particular:

1. the costs of emergency interventions undertaken at the time of the damage, and necessary to limit and prevent the effects of damage on the environment, space, and health of the population;

2. direct and indirect costs of remediation, the establishment of a new state or restoration of the previous state of the environment and space, as well as monitoring of the effects of remediation and the effects of damage to the environment;

3. costs of preventing the occurrence of the same or similar damage to the environment and space;

4. costs of compensation to persons directly endangered by damage to the environment and space. 
In addition to the above, paragraphs 2 and paragraph 3 of the same article also stipulate that "the polluter is obliged to provide financial or other types of guarantees to ensure the payment of compensation for the mentioned costs during and after the performance of activities. The type of guarantees, the amount of funds, and the duration of the guarantee provided by the polluters shall be prescribed by the Government of the Republic of Serbia."

In situations where there are circumstances in which the plants or activities of polluters pose a high degree of danger to human health and the environment, Article 6 of the Law on Environmental Protection (2004) provides for the obligation to insure against liability for damage caused to third parties by accident.

In case certain damage has occurred due to the activity of the polluter, Article 107 of the same law, in paragraphs 1 and 2 prescribes that "everyone who suffers damage has the right to compensation, whereby a claim for compensation can be submitted directly to the polluter or insurer, or to the financial guarantor of the polluter if such an insurer or financial guarantor exists." Paragraph 3 stipulates that in the event of the existence of "several pollutants who are responsible for the damage caused to the environment, and the share of individual pollutants cannot be determined, the costs shall be borne jointly and severally."

In this part, it should be emphasized that "civil sanctions are determined against the debtor as a mechanism of coercion over the damaged, to bring property or personal non-property goods in a state in which they would be if there was no threat or violation of these values" (Nikolić, 2007, p. 142).

Civil liability for the harmful consequences of environmental pollution is primarily regulated by the Law on Environmental Protection (2004), while the Law on Obligations (1978) applies in all matters of liability for environmental damage not regulated by the Law on Environmental Protection. as referred to in Article 108 of this Law).

\section{Council of Europe Convention on Civil Liability for Damage Caused by Activities Dangerous to the Environment}

In 1993, the Council of Europe adopted the Convention on Civil Liability for Damage Caused by Activities Dangerous to the Environment (hereinafter: the Convention), to improve the quality of the environment and cooperation between states in the field of environmental protection. Arsic (2014) points out that "the Convention aims to provide adequate compensation for damage caused as a result of activities that are dangerous to the environment" (p. 92). 
Based on the "polluter pays" principle, this Convention, "by a broad definition of liability, facilitates the burden of proving to claimants the right to compensation. The Convention applies to all-natural and legal persons who have influence and control over the performance of certain dangerous activities" (Pajtić, 2011a, p. 520).

According to Article 2, paragraph 7, items a and $b$ of the Convention, "damage includes injury to persons or loss of life, damage to property of a person, excluding damage to a plant or property operated by a carrier of lifethreatening activities".

Items $\mathrm{c}$ and $\mathrm{d}$ of the mentioned article and paragraph stipulate that "compensation for damage includes compensation for damage caused by damage to the quality of the environment and compensation for damage directly caused to persons or their property. Compensation for damage caused by damage to the quality of the environment refers to lost profits due to impaired quality of the environment. Compensation for damage caused by damage to the quality of the environment also includes the costs of taking measures taken at the time of the damage that was necessary to prevent the effects of the damage and measures that return the environment to its previous state."

The Convention defines the notion of dangerous activity in Article 2, paragraph 1, item c. According to these provisions, "hazardous activity is any activity related to the production, handling, storage or use of one or more hazardous substances, any activity carried out at a place intended for permanent storage of waste, as well as activities carried out during the operation of the plant for incineration, treatment, handling and recycling of waste."

Dangerous activity is also considered "production, handling, storage, destruction, disposal, release or any other activity that involves the manipulation of genetically modified organisms or microorganisms, if such activities may pose a risk to the environment, human health or their property" ( Article 2, paragraph 1 , item $b$ of the Convention), while a dangerous substance is considered to be "a substance of certain physical and chemical properties that carries a significant risk to the environment, human health and property" (Article 2, paragraph 2 of the Convention).

According to Drenovak Ivanović et al. (2015), and following Article 3 of the Convention, "the basic idea of the Convention refers to the obligation to apply it in all cases where an environmental incident has occurred in the territory of a member state of the Convention, regardless of whether the consequences are felt. only in the territory of the member states of the Council of Europe or abroad" (p. 31). In doing so, Article 2, paragraph 11 defines the notion of an incident, which, according to the provisions, "could 
be a sudden event, an event that recurs continuously or a series of events that have the same origin. To be considered an incident within the meaning of the Convention, these events must be of such intensity that their occurrence causes damage or poses a serious and imminent danger of harm."

According to the provisions of Article 10 of the Convention, "liability for damages is determined by the rules on strict liability" because liability is based on the selfconscious risk assumed in performing dangerous activities. Article 8, paragraph 1, item a, stipulates that "objective liability for damage caused by environmentally hazardous activities may be excluded if the holder of the environmentally hazardous activity proves that the damage occurred as a result of a state of war or riot, or a natural phenomenon that is not common for the area in which the damage occurred, which could not have been avoided" or if following point $b$ of the same paragraph and article "it is proved that the damage occurred as a result of the activities of a third party who intended to cause damage and who this intention succeeded despite the application of safety measures appropriate to the type of hazardous activities in the particular case" or if following points $\mathrm{c}$ and e "damage caused by the application of measures taken by the competent authority or if the damage was caused by pollution within national limits on limit values in a certain area."

\section{Directive of the European Parliament and the Council on liability for environmental damage relating to the protection and remedying of environmental damage}

The Directive of the European Parliament and the Council on liability for environmental damage relating to the protection and remedying of environmental damage (hereinafter: Directive 2004/35/CE) regulates environmental liability and the prevention and remedying of damage caused to the environment. According to Pajtić (2011b), "Directive 2004/35/CE provides the direct application of the polluter pays principle, introduces the concept of ,environmental damage", and numerous measures and procedures to prevent and eliminate the damage. The basic principle on which Directive 2004/35/CE is based in the establishment of financial responsibility of operators whose actions cause environmental damage or the danger of such damage, which encourages operators to adopt measures and develop procedures to reduce the risk of environmental damage, and thus their responsibility and financial exposure" (p. 261).

The question of how to determine the damage to the environment can often be very complex. Drenovak Ivanović et al. (2015) points out that in some cases "by applying the rules of civil law on compensation for damage, adequate 
compensation for damage to the environment cannot be made, because it is very difficult or almost impossible to determine who the source of pollution is, and in other cases, it can identify a person who has suffered specific damage, but it is a violation that has a predominant public character" (p. 54).

Following the provisions of Article 2, paragraph 2 of Directive 2004/35/ $\mathrm{CE}$, the damage is defined as "a measurable adverse change in a natural good or a measurable impairment of the functions of a natural good that may arise as a direct or indirect consequence of an activity." Directive 2004/35 / EC does not apply to any damage to the environment, but to the damage explicitly stated therein. The directive "refers to future damage concerning the moment of entry into force, ie. application in national legislation. The directive has no retroactive effect" (Pajtić, 2011b, p. 261).

It is important to note that by the provisions of Article 3, paragraph 3 of Directive 2004/35 / EC, "natural and legal persons may not invoke the Directive with a claim for damages to their life and health or property caused by damage to life. the environment or the imminent danger of its occurrence". These rights are regulated by "national legislation, and the Council of Europe Convention on Civil Liability for Damage Caused by Activities Dangerous to the Environment (1993) provides basic guidelines for compensation for damage caused to natural and legal persons. However, persons affected by or likely to be affected by environmental damage, following Directive 2004/35/ $\mathrm{CE}$, have the right to request the application of appropriate protection measures from the competent authority, as well as to participate in the review of decisions, actions or omission of actions by the competent authority related to environmental protection" (Drenovak Ivanović et al., 2015, p. 56).

Directive 2004/35/CE refers to "operators of regulated activities, and this includes most industrial activities - e.g. chemical industry, waste management, transport and handling of hazardous substances or genetically modified organisms" (Pajtić, 2011b, p. 262).

Directive 2004/35/CE, under the provisions of Article 3 (1), introduces a distinction between "damage to the environment caused or which may result from particularly dangerous activities listed in Annex III to the Directive, and damage caused to protected species and natural habitats and which arose from the performance of activities not listed in Annex III of the Directive, and which the operator caused by acting with intent or negligence." According to Drenovak, Ivanović, and associates (2015), "in the first case, the operator is liable for damage according to the principle of objective liability for damage caused to the environment and any of its media. In the second case, the operator is liable for damage based on fault (subjective liability) for causing 
damage, but not to any environmental medium, but only to protected species and natural habitats" (p. 58). In this context, Pajtić (2011b) states that Directive 2004/35/CE "adopts the principle of strict liability for operators of environmentally hazardous activities, which are listed in Annex 1 of the Directive. For all other activities outside Annex 1, Directive 2004/35/CE provides for liability under the principle of fault. While strict liability covers all types of environmental damage, liability under the guilt principle applies only to damage to the ecological system" (p. 262).

Following the provisions of the Directive, operators are obliged to inform the competent authorities about the environmental damage that may occur as a result of their activities, as well as to take appropriate measures to control, limit, secure, eliminate and manage the damage.

According to Article 8 of Directive 2004/35/CE, "the costs of measures to prevent and eliminate damage to the environment shall be borne by the operator." In that context, there are different measures of protection and measures to eliminate harmful consequences. Pajtić (2011b) points out that "Directive 2004/35/CE defines protection measures as measures taken in response to an event, action or omitted action which created an immediate threat of environmental damage, and which aim to prevent or mitigate the consequences of such damage. Remediation measures are defined as measures or a combination of measures, including damage management measures or temporary measures to eliminate damage, rehabilitation or replacement of damaged natural resources and/or similar measures, or provision of resources equivalent to damaged resources" (p. 263).

\section{Conclusion}

The right to a healthy environment is an absolute priority of modern society. Responsible approach and active role of potential polluters in the development of good practices within the business, organization, and way of working play a significant role in the prevention of damages and dangers that can harm the environment. Equally significant impact has the continuous professional development of employees, as well as strengthening the environmental awareness of polluters, with the insistence on the application of all available measures and prevention procedures.

A specific economic instrument aimed at protecting the environment at the global level is the compensation for environmental pollution, based on a special principle of environmental protection called "polluter pays". The introduction of this principle into our legislation is legally based on international 
regulations. The essence of this concept relies on the voluntary active participation and contribution of polluters in creating a responsible approach and preventing potential dangers and damages that would harm the environment. In other words, the essence of civil liability for damage that a polluter can cause to the environment is that potential polluters adjust their activities to the requirement to cause minimal changes in the environment and reduce the risk of damage to a minimum.

Having in mind that the national legislation is based on the legal framework of the European Union, the paper presents the significance and characteristics of the "polluter pays" principle, the provisions of the Law on Environmental Protection, analyses the provisions of the Europe Convention Council regarding civil liability arising from activities dangerous to the environment (1993), and the provisions of the European Parliament Directive and the Council on liability for environmental damage related to the protection and elimination of environmental damage (Directive 2004/35/CE).

\section{Drašković Bojana}

Vanredni profesor, Fakultet za građevinski menadžment, Univerzitet „Union-Nikola Tesla“, Srbija

\section{Perović Olga}

Master prava, doktorantkinja, Pravni fakultet za privredu i pravosuđe u Novom Sadu, Univerzitet Privredna akademija u Novom Sadu, Srbija

\section{ZNAČAJ NAČELA,ZAGAĐIVAČ PLAĆA“ I ANALIZA EVROPSKOG OKVIRA GRAĐANSKOPRAVNE ODGOVORNOSTI ZA ŠTETE NASTALE USLED DELATNOSTI OPASNIH PO ŽIVOTNU SREDINU}

REZIME: Pravo na zdravu životnu sredinu je apsolutni prioritet savremenog društva. Poseban ekonomski instrument usmeren ka zaštiti životne sredine na globalnom nivou jeste naknada za zagađivanje životne sredine, zasnovana na posebnom načelu zaštite životne sredine pod nazivom ,za- 
gađivač plaća”. Suština građanskopravne odgovornosti za štete u životnoj sredini jeste to da potencijalni zagađivači svoje aktivnosti prilagode zahtevu da se prouzrokuju minimalne promene u životnoj sredini i rizik nastupanja štete svede na najmanju moguću meru. U radu su pored značaja i karakteristika načela „zagađivač plaća“, predstavljene odredbe Zakona o zaštiti životne sredine, a potom su predmet analize bile odredbe Konvencije o građanskoj odgovornosti za štete nastale usled aktivnosti opasnih po životnu sredinu, kao i odredbe Direktive o odgovornosti za ekološku štetu u vezi sa zaštitom i otklanjanjem ekološke štete.

Ključne reči: zagađivač plaća, životna sredina, građanskopravna odgovornost, Zakon o zaštiti životne sredine, EU regulativa

\section{References}

1. Arsić, Z. (2014). Konvencija o građanskoj odgovornosti za štete nastale usled delatnosti opasnih po životnu sredinu [Convention on Civil Liability for Damage Caused by Activities Dangerous to the Environment]. Zbornik radova Pravnog fakulteta u Novom Sadu, 41 (1), pp. 91-103

2. Bingulac, N., \& Milojević, G. (2018). Zakonska regulative koja definiše princip ,zagađivač plaća" [Legislation defining the "Polluter pays" principle]. In: Ljumović, I., Stevanović, S. (eds.), Pravni i ekonomski aspekti primene principa ,zagađivač plaća” [Legal and Economic aspects of application of the "Pollution pays" principle] (pp. 197-213). Beograd: Institut ekonomskih nauka

3. Cvetić, R. (2013). Zaštita životne sredine - pomeranje težišta ka zaštitnom objektu [Environmental protection - moving the center of gravity towards the protective object]. Zbornik radova Pravnog fakulteta $u$ Novom Sadu, 47 (4), pp. 117-129

4. Cvijanović, D., Matijašević Obradović, J., \& Škorić, S. (2017). The Impact of Air Quality Conditioned by Emission of Poluttants to the Development of Rural Tourism and Potentials of Rural Areas. Economics of Agriculture, 64 (3), pp. 871-885

5. Convention on Civil Liability for Damage Resulting from Activities Dangerous to the Environment, ETS No. 150, Lugano, 21.VI.1993

6. Directive 2004/35/CE of the Europen Parliament and of the Council of 21 April 2004 on environmental liability with regard to the prevention and remetyng of envronmental domage, OJ L 143 
7. Drenovak Ivanović, M., Đorđević, S., \& Važić, S. (2015). Pravni instrumenti ekološke zaštite - građanskopravna i krivičnopravna zaštita [Legal instruments of environmental protection - civil and criminal protection]. Beograd: Organization for Security and Co-operation in Europe

8. Đorđević, M. (2018). Zagađivanje i zaštita vazduha, vode i zemljišta [Pollution and protection of air, water and soil]. Vojno delo, 70 (7), pp. 465-474

9. Hamidović, Dž. (2012). Krivičnopravna zaštita životne sredine i održivi razvoj naše zemlje [Criminal protection of the environment and sustainable development of our country]. Socioeconomica, 1 (2), pp. 235-245

10. Jovašević, D. (2009). Evropski standardi i zaštita životne sredine [European standards and environmental protection]. Evropsko zakonodavstvo, 8 (8), pp. 125-141

11. Keković, Z., \& Todorović, Z. (2008). Ugrožavanje životne sredine u Republici Srbiji - bezbedonosni aspekt [Endangering the environment in the Republic of Serbia - security aspect]. NBP- žurnal za kriminalistiku i pravo, 13 (3), pp. 23-40

12. Labudović Stanković, J. (2012). Osiguranje od odgovornosti za štete prouzrokovane životnoj sredini [Liability insurance for damage caused to the environment]. Teme, 36 (3), pp. 1261-1278

13. Matijašević Obradović, J. (2017). Značaj zaštite životne sredine za razvoj ekoturizma u Srbiji [The importance of environmental protection for the development of ecotourism in Serbia]. Agroekonomika, 46 (75), pp. 21-30

14. Nikolić, D. (2007). Uvod u sistem građanskog prava [Introduction to the civil law system]. Novi Sad: Centar za izdavačku delatnost Pravnog fakulteta Univerziteta u Novom Sadu

15. OECD (1974). Recommendation of the Council on the Implementation of the Polluter-Pays Principle, OECD/LEGAL/0132

16. Pajtić, B. (2011a). Ekološka odgovornost [Environmental responsibility]. Zbornik radova Pravnog fakulteta u Novom Sadu, 45 (3), pp. 517-531

17. Pajtić, B. (2011b). Zaštita životne sredine - prevencija i naknada štete [Environmental protection - prevention and compensation]. Zbornik radova Pravnog fakulteta u Novom Sadu, 45 (2), pp. 249-264

18. Pajtić, B. (2015). Građanskopravna odgovornost zbog zagađivanja životne sredine [Civil liability for environmental pollution]. Zbornik radova Pravnog fakulteta u Novom Sadu, 49 (4), pp. 1669-1679

19. Počuča, M., \& Milić, M. (2018). Analiza pravnih akata lokalne samouprave koji se odnose na princip ,zagađivač plaća“ u Srbiji [Analysis of 
legal acts of local self-government related to the principle of "Polluter pays" in Serbia]. In: Ljumović, I., Stevanović, S. (eds.), Pravni i ekonomski aspekti primene principa ,zagađivač plaća” [Legal and Economic aspects of application of the "Pollution pays" principle] (pp. 233-250). Beograd: Institut ekonomskih nauka.

20. Popov, D. (2013). Načela zaštite životne sredine u dokumentima Ujedinjenih Nacija, Evropske unije i Zakona o zaštiti životne sredine Republike Srbije [Principles of environmental protection in the documents of the United Nations, the European Union and the Law on Environmental Protection of the Republic of Serbia]. Zbornik radova Pravnog fakulteta u Novom Sadu, 47 (2), pp. 131-146

21. Salma, J. (2009). Obligacionopravna zaštita životne sredine [Environmental protection according to the norms of the Law of obligations]. Zbornik radova Pravnog fakulteta u Novom Sadu, 43 (2), pp. 33-53

22. Tubić, B. (2012). Pravna načela u oblasti zaštite životne sredine u Evropskoj uniji [Legal principles in the field of environmental protection in the European Union]. Zbornik radova Pravnog fakulteta u Novom Sadu, 46 (1), pp. 491-506

23. Ustav Republike Srbije [Constitution of the Republic of Serbia]. Službeni glasnik $R S$, br. $98 / 06$

24. Zakon o zaštiti životne sredine [Law on Environmental Protection]. Službeni glasnik RS, br. 135/04, 36/09, 36/09 - dr. zakon, 72/09 - dr. zakon, 43/11 - odluka US, 14/16, 76/18, 95/18 - dr. zakon i 95/18 - dr. zakon

25. Zakon o integrisanom sprečavanju i kontroli zagađivanja životne sredine [Law on Integrated Prevention and Control of Environmental Pollution]. Službeni glasnik $R S$, br. 135/04 i 25/15

26. Zakon o obligacionim odnosima [Law on Obligations]. Službeni list SFRJ, br. 29/78, 39/85, 45/89 - odluka USJ i 57/89, Službeni list SRJ, br. 31/93, Službeni list SCG, br. 1/03 - Ustavna povelja i Službeni glasnik $R S$, br. $18 / 20$

27. Zindović, I. (2012). Oblici pravne odgovornosti u kontekstu zaštite životne sredine [Forms of legal liability in the context of environmental protection]. Evropsko zakonodavstvo, 11 (41), pp. 270-285 